\title{
United we claim, divided we act: Managing diversity in post-colonial Nigeria
}

Joseph Egwurube

\section{OpenEdition}

1 Journals

Electronic version

URL: https://journals.openedition.org/eastafrica/408

DOI: 10.4000/eastafrica.408

ISSN: 2790-1076

Publisher

IFRA - Institut Français de Recherche en Afrique

Printed version

Date of publication: 1 September 2013

Number of pages: $71-86$

ISSN: 2071-7245

\section{Electronic reference}

Joseph Egwurube, "United we claim, divided we act: Managing diversity in post-colonial Nigeria", Les

Cahiers d'Afrique de l'Est / The East African Review [Online], 47 | 2013, Online since 07 May 2019,

connection on 09 December 2021. URL: http://journals.openedition.org/eastafrica/408; DOI: https:// doi.org/10.4000/eastafrica.408 


\title{
United we claim, divided we act: Managing diversity in post-colonial Nigeria
}

\author{
Joseph Egwurube
}

\author{
Nigeria, Africa's colossus, is an enigma. What is it and \\ what does it want to be: a unified nation or a collection of \\ autonomous, balkanized states?' (Morris-Hale 1997: 191).
}

\section{Introduction}

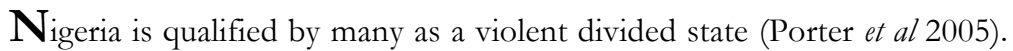
With more than 390 ethnic groups, 36 states, and 774 local government areas, it is home to a plurality of identity constellations, including ethno-regional, territorial, gender, and religious ones, which are often in opposition for several reasons including the fact that they compete for access to political, economic and administrative resources in the context of a winner-take-all prebendal framework of politics (Richard 1991). The difficulties of managing the mosaic of identity constellations can be gauged in the more than 2 million lives claimed by the three-year civil war fought between 1967 and 1970 to contain Biafran irredentism as well as the high frequency of inter-communal and inter-religious crises in recent times that have equally left in their wake thousands of deaths.

This paper focuses on only one aspect of diversity in Nigeria, intercommunal or inter-ethnic diversity. Even though inter-religious problems have contributed to the divisions within the Nigerian society, the civil wartime slogan of 'To keep Nigeria one is a task that must be done', which seems to have been accepted as the goal of successive regimes in the country since then, has a primary territorial-cum-inter-ethnic rather than an inter-religious focus. In exploring the management of inter-communal diversity, we have a number of working hypotheses. The first is that there is inter-communal distance rather than proximity in the country, a 'we' versus 'them', 'us' versus 'others' dichotomies guiding how each of the specific ethno-regional groups relates to the others. The second is that this distance is a direct result of the dominance of negative heterostereotypes in inter-communal relations. The third is that this distance is sometimes artificially maintained or exaggerated by some political and social actors who use them in their quest to obtain easier access to centers of power, which by definition are where key political and especially economic/financial resources are located. We are going to try to confirm these hypotheses by using some of the results of field work done in Nigeria on the question of inter-group 
contact and perceptions in 2011. Before this, we will first identify and explore some of the key concepts we will be using, such as intergroup relations, interculturalism, ethnic conflicts and multination federalism.

\section{Theoretical Considerations}

The management of multi-ethnic societies and intergroup relations has attracted lots of academic interest in recent years (Kymlicka \& Norman 2000, Kymlicka 2001). One of the reasons behind such interest is the ubiquity of problems of managing ethno-cultural diversity worldwide, centrifugal ethnocultural and regional movements calling into question the territorial integrity of such stable democracies like Belgium as much as relatively unstable post-colonial states like Nigeria. A number of themes are examined under the banner of intergroup relations to which we will be making reference in our work. The first is of course the question of stereotypes. Stereotypes "constitute people's beliefs about groups - beliefs that may be positive or negative, accurate or inaccurate" (Yueh-Ting 1995: 6). They may lead to prejudice or "negative attitudes towards members of socially defined groups" (Stephan \& Stephan 1996: 34). Such prejudice may then bring about discrimination towards members of the stereotyped category. Even though there is no direct relation between the nature of stereotypes and level of intergroup contact, we will also be using the latter concept in our study. Our thinking is that the level of intergroup contact determines significantly the degree of anxiety members of one group have in their interactions with members of other groups. According to Stephan and Stephan, intergroup anxiety is usually generated by factors such as "minimal prior contact", "low knowledge regarding the other group" and "high levels of prejudice and stereotyping" (Stephan \& Stephan 1996: 129). Paradoxically, anxiety tends to diminish the positive effects of inter-group contact by making it impossible to achieve optimum group contact and understanding (Hewstone 1996).

Within the context of intergroup relations, we will also be dealing with the question of intercultural relations and ethnic conflicts. Intercultural behavior revolves around the study of individual and group differences and how groups interact. The way different types of groups (majority/minority, dominant/subordinate etc) relate interculturally (assimilation, integration, separation etc) has been examined by many authors (Berry 1999). Our opinion is that the management of interculturality will depend on such factors as types of inter-cultural stereotypes and prejudice, level of inter-cultural contact as we said above, as well as relative degrees of tolerance and acceptance of other cultures. There is a tendency to study intergroup and intercultural relations from the perspective of intergroup conflicts. As far as Nigeria is concerned, such an approach has meant focusing attention on ethnic conflicts, many writers believing the single most important challenge of Nigeria, like other post-colonial African countries, to be that of nation-building or the construction of a single national identity in a multi ethnic or multinational environment (Rothchild 1997). The ethnic conflict approach has led to the identification of different types of 
regime in Africa, from the polyarchical through elite power-sharing to hegemonic regimes which have been used in several African countries to manage inter-ethnic cooperation and reduce conflicts (Ibid: 11-12). Our focus is as much on interethnic perceptions and the possible conflicts that may arise as a result as on institutional mechanisms used by Nigeria to encourage inter-communal coexistence and harmony. We will therefore address the question of multination federalism. Multination federalism is different from territorial federalism because unlike in territorial federalism, exemplified by the USA, where "a single national community can divide and diffuse power", multination federalism is designed to accommodate ethno-cultural groups (Resnick 1994: 71). Nigeria is a perfect example of multination federalism because the federal solution, a loose form of togetherness, was chosen to deal with ethnic and cultural pluralism as well as immediately contain Biafran secession (Allan Tarr et al, 2004). As an institutional tool for accommodating multinationality or distinct ethno-regional identities, Nigerian federalism epitomizes an incongruent rather than a congruent structure (Lijphat 1984). It is incongruent because the internal political boundaries coincide with ethnic and cultural boundaries. There is a match between the constituent elements of the federation and ethno-cultural 'homelands'. Such an approach has a direct influence on inter-communal rapport and on the existence of distance or proximity between the federated communities.

\section{Inter-communal distance or proximity}

Our study of inter-communal distance is based on field work on intergroup contact and perceptions carried out in Nigeria in 2011. We administered a questionnaire to a purposively selected sample of 600 Nigerians in the Federal Capital Territory and in two states, Kaduna in the north, and Benue in the Middle Belt. The questions were on perceptions of respondents about people from ten different ethnic groups, including the three dominant ones (the Hausa/Fulani, the Yoruba and the Ibo) and seven others spread across the country (the Nupe, and Kanuri in northern Nigeria, the Tiv and Jukun in the Middle Belt and the Efik, Itsekiri and Ogoni in southern Nigeria). The respondents were chosen in such a way to include people from the three 'natural regions' in the country, the North, the Middle Belt and the South, the two dominant religions, both sexes and the young, middle aged and the old. In addition, we chose respondents whose professional lives brought them into contact with as many ethnic groups as possible. Out of the 600 questionnaires administered, 301 were returned. A breakdown is shown in Table 1. 
Table 1: Profession, Regional Origin, Age, Religion and Sex of Respondents to questionnaire on Inter-group relations in Nigeria (August 2011). N=301

\begin{tabular}{|l|l|l|l|}
\hline Profession & \multicolumn{1}{|c|}{ Male } & Female & Total \\
\hline Student & 9 & 43 & 102 \\
\hline Civil Servant & 9 & 27 & 66 \\
\hline Liberal profession* & 0 & 6 & 26 \\
\hline Top economic actor** & 4 & 27 & 51 \\
\hline Trader & 8 & 6 & 24 \\
\hline Private sector employee & 5 & 4 & 29 \\
\hline Others*** & 3 & & 3 \\
\hline Geographical origin & & & \\
\hline $\begin{array}{l}\text { Respondents from the } \\
\text { North }\end{array}$ & 8 & 40 & 98 \\
\hline $\begin{array}{l}\text { Respondents from the } \\
\text { Middle Belt }\end{array}$ & 2 & 42 & 104 \\
\hline $\begin{array}{l}\text { Respondents from the } \\
\text { South }\end{array}$ & 8 & 31 & 99 \\
\hline Age & & & \\
\hline Less than 20 & 0 & 7 & 171 \\
\hline 20 to 40 & 6 & 75 & 94 \\
\hline 41 to 60 & 63 & 31 & 28 \\
\hline Above 60 & 28 & 0 & 124 \\
\hline Religion & & 47 & 189 \\
\hline Muslim & 94 & 65 & \\
\hline Christian & 7 & 1 & \\
\hline Traditional & & & \\
\hline
\end{tabular}

$*_{\text {includes medical doctors and lawyers }}$

**includes top industrialists, bankers and key businessmen

$* * *$ includes retired people

A number of observations can be made on our field work. There are obviously a number of limits, the most important being the relatively small size of our sample when measured against the total population of Nigeria. Such a small size notwithstanding, we think answers given by our 301 respondents would enable us to have an idea of how some communities in the country are perceived. A second limit could be our choice not to break the respondents down into ethnic categories in order for example to see how Yoruba respondents view themselves and others. We did not ask our respondents to indicate their ethnic origins because our study does not wish to examine in-group and outgroup stereotypes. This will be the object of future field work in Nigeria. A few respondents indicated their ethnic origins but the samples are not large enough to make generalized statements about how one ethnic group views another.

Using such a representative sample of Nigerians, our aim was to explore levels of inter-communal contact, images held on the ten selected ethnic groups, how respondents react when they meet people from them and their preparedness to allow intermarriages to members of each of these different ethnic groups. 
One of the questions we asked our respondents was the frequency with which they meet people from different ethnic groups. Their responses are shown in Table 2 below.

Table 2: Frequency of contact by respondents with people from different ethnic groups $(\mathrm{N}=301)$

\begin{tabular}{|l|c|c|}
\hline Frequency of contact & Male Respondents & Female Respondents \\
\hline Very frequent & $53 \%$ & $59 \%$ \\
\hline Occasional & $39 \%$ & $33 \%$ \\
\hline Rare & $6 \%$ & $4 \%$ \\
\hline No contact at all & $0.5 \%$ & $0 \%$ \\
\hline
\end{tabular}

We observe a relatively high level of contact between our respondents and people from different ethnic groups. This tends to show that rather than have a system of closure and distance towards others who are from different ethnic extractions, there is in reality regular contact and thus proximity in social relations. From an inter-personal level, there are thus lots of interaction bridges established between people from different ethnic groups. It is however important to gauge the nature of such bridges and the quality of the contacts that flow under them. This we tried to measure in terms of whether contact between respondents and people from the ten selected ethnic groups were formal administrative, commercial, religious or informal friendship relations. Our thinking is that the less informal the nature of such rapport, the deeper and more intimate they are and so the better the knowledge of otherness. The responses of our field work are shown in Table 3.

Table 3: Nature of contact between Respondents and people from ten selected ethnic groups $(\mathrm{N}=301)$

\begin{tabular}{|l|l|l|l|l|}
\hline Ethnic group & Commercial & Administrative & Friendship & Religious \\
\hline Hausa/Fulani & $30 \%$ & $28 \%$ & $47 \%$ & $15 \%$ \\
\hline Yoruba & $21 \%$ & $28 \%$ & $49 \%$ & $18 \%$ \\
\hline Ibo & $51 \%$ & $11 \%$ & $40 \%$ & $11 \%$ \\
\hline Kanuri & $35 \%$ & $30 \%$ & $36 \%$ & $15 \%$ \\
\hline Efik & $17 \%$ & $35 \%$ & $41 \%$ & $11 \%$ \\
\hline Tiv & $26 \%$ & $24 \%$ & $51 \%$ & $12 \%$ \\
\hline Nupe & $31 \%$ & $19 \%$ & $48 \%$ & $14 \%$ \\
\hline Itsekiri & $27 \%$ & $30 \%$ & $41 \%$ & $13 \%$ \\
\hline Jukun & $30 \%$ & $19 \%$ & $39 \%$ & $14 \%$ \\
\hline Ogoni & $31 \%$ & $25 \%$ & $38 \%$ & $12 \%$ \\
\hline
\end{tabular}


The single most important information provided by the above table is the predominance of informal friendship ties between our respondents and members of the selected ethnic groups. The predominance of such informal and intimate relations would appear to contradict the dominant thinking that contact between ethnic groups is acrimonious and cut-throat competitive. In reality, we believe that there is no contradiction because the relations shown above are in the final analysis inter-individual rather than inter-group. Apart from the Ibos, where more respondents report having more commercial than other forms of individual contact, friendship is the most highly cited form of links with people from the other ethnic groups. In our opinion, this translates an opposition in the nature of inter-individual and inter-group relations. The former appear cohesive while the latter are usually described as competitive, conflict ridden and hostile. The cohesive inter-individual rapport across different cultures notwithstanding, we tried to see how respondents perceived the ten ethnic groups under study by indicating how they generally react when they meet people from such groups that they have never met before. Their responses are in Table 4 below.

Table 4: How respondents react when they meet people from ten ethnic groups (Multiple choice possible) $(\mathrm{N}=301)$

\begin{tabular}{|l|l|l|l|l|l|}
\hline $\begin{array}{l}\text { Ethnic } \\
\text { group }\end{array}$ & Relaxed & Suspicious & $\begin{array}{l}\text { Anxious/ } \\
\text { Tense }\end{array}$ & $\begin{array}{l}\text { Feel } \\
\text { threatened }\end{array}$ & $\begin{array}{l}\text { No reation } \\
\text { (neither positive } \\
\text { nor negative }\end{array}$ \\
\hline $\begin{array}{c}\text { Hausa/F } \\
\text { ulani }\end{array}$ & $55 \%$ & $21 \%$ & $15 \%$ & $17 \%$ & $16 \%$ \\
\hline Yoruba & $38 \%$ & $31 \%$ & $13 \%$ & $6 \%$ & $27 \%$ \\
\hline Ibo & $18 \%$ & $58 \%$ & $9 \%$ & $13 \%$ & $20 \%$ \\
\hline Kanuri & $22 \%$ & $24 \%$ & $3 \%$ & $15 \%$ & $39 \%$ \\
\hline Efik & $13 \%$ & $36 \%$ & $7 \%$ & $15 \%$ & $36 \%$ \\
\hline Tiv & $34 \%$ & $28 \%$ & $16 \%$ & $6 \%$ & $29 \%$ \\
\hline Nupe & $28 \%$ & $24 \%$ & $9 \%$ & $25 \%$ & $37 \%$ \\
\hline Itsekiri & $19 \%$ & $22 \%$ & $14 \%$ & $14 \%$ & $39 \%$ \\
\hline Jukun & $19 \%$ & $26 \%$ & $17 \%$ & $13 \%$ & $34 \%$ \\
\hline Ogoni & $13 \%$ & $25 \%$ & $14 \%$ & $20 \%$ & $39 \%$ \\
\hline
\end{tabular}

Several readings can be made on the above table. The first is that only with the Hausa Fulani do more than half of our respondents report a relaxed form of contact. The same proportion reports being suspicious when they meet Ibo people. However, more than a third of our respondents each time report no reaction whatsoever when they come into contact with people from our ten selected ethnic groups. This would tend to indicate the absence of anxiety when contact is established with members of other ethnic groups. However, we do not really know if such absence of anxiety in contacts with members of other groups suggests openness towards the same category of people. We therefore tried to measure the degree of such openness by asking our respondents how willing they 
were to accept marriage to people from the ten ethnic groups in question. In social science literature, one key indicator of social distance among groups or the quality of societal cohesion is intermarriage because mixed marriages link individuals but also serve as bridges between the larger groups to which such individuals belong (Monden\& Smits 323). Responses to this question are shown in Table 5 .

Table 5: Measuring prejudice and/or openness - Preparedness of respondents to inter-marriage to people from ten selected ethnic groups $(\mathrm{N}=301)$

\begin{tabular}{|l|ll|}
\hline \multicolumn{1}{|c|}{ Ethnic groups } & \multicolumn{2}{c|}{ Accept Marriage to } \\
& Yes & No \\
\hline Hausa/Fulani & $52.4 \%$ & $43.8 \%$ \\
\hline Yoruba & $60.7 \%$ & $34.2 \%$ \\
\hline Ibo & $46.1 \%$ & $49.5 \%$ \\
\hline Kanuri & $37.2 \%$ & $53.1 \%$ \\
\hline Efik & $31 \%$ & $51.5 \%$ \\
\hline Tiv & $37 \%$ & $52.1 \%$ \\
\hline Nupe & $52 \%$ & $43 \%$ \\
\hline Itsekiri & $39 \%$ & $57 \%$ \\
\hline Jukun & $36 \%$ & $59 \%$ \\
\hline Ogoni & $31 \%$ & $57 \%$ \\
\hline
\end{tabular}

*Total responses are less than $100 \%$ because not all the questionnaires were filled in.

From the above table it is possible to identify the existence of some prejudice and bias against members of the selected ethnic groups. Only towards the Hausa, the Yoruba and the Nupe are more respondents willing to accept marriage relations than unwilling to. Such willingness is all the more relative since at least over a third of the respondents refuse marriages to members of the three groups indicated. For the other seven groups under study, there are more respondents unwilling than willing to accept inter-marriages. Since intermarriage is an indicator or measure of the degree of social distance between groups, we may say that the closure of respondents to such a cementing agent translates an unwillingness for deeper and longer lasting union with people from other cultural backgrounds. There thus appears to be a refusal to bridge the gap between the 'us' versus 'them' constructs and the implicit intention of wishing to maintain the inclusive and exclusive membership composition of ethnic groups. Such an intention translates the existence of an in-group/out-group schism which we think has a number of origins one of which is the predominance of negative hetero-stereotypes in inter-communal perceptions. 


\section{Negative stereotypes of others}

A reading of some existing literature on inter-communal relations in Nigeria shows how many groups have quite negative perceptions of other similar groups in the country. Negative hetero-stereotypes have different foundations, ethnic, geographical and religious. From an inter-ethnic point of view, there are deriding and sometimes very insulting images held by one group concerning the others. This is especially true in the perceptions held by the three major ethnic groups, the Hausa, the Ibo and the Yoruba one about the others. As early as the immediate post-independent era, Obafemi Awolowo, who is of Yoruba origin and who had taken an active part in the struggle for Nigerian independence, conceived the Hausa and Yoruba as being more 'civilized' than the Ibo, because they had well-established forms of government before the arrival of the British (Onwubu 1975). The Ibo system was derided by Awolowo as being 'the worst' because highly individualistic. Such a negative hetero-perception hardly matches the definition offered by the Ibos about their cultural wealth. For example, the Ibos view themselves as having a higher educational level compared to other groups with particular reference to 'Northerners' (Ibid. 1975), a blanket term which in reality refers particularly to the Hausa/Fulani, usually looked down upon due to their supposedly relatively weak educational performance levels

Sometimes, negative inter-ethnic group stereotypes have deeply religious undertones. For example the negative hetero-stereotyping images that have been identified in Ibo-Hausa relations are conditioned by a religious aspect. The Ibos perceive the Islamized Hausa as strange, highly unrefined and uncivilized while the non-muslim Ibo is regarded by the Hausa Muslim as an infidel that needs to be kept at arm's length (Oha 2001). Even within the same religious groups, there are negative definitions of the 'others' on the ground of their being from different ethnic origins. For example, the Hausa who live in Jos, a city in central Nigeria that has been the theatre of numerous inter-religious (Christian versus Moslem) conflicts, and who call themselves the Jasawa' look down on other nonHausa muslim populations in the same territory as 'munafiki', traitors or hypocrites (Ostein 2009). This is because the non-Hausa Muslims consider their Hausa counterparts as 'settlers' in the region and thus as having less legitimacy than them to have access to political, administrative and economic advantages distributed by city authorities. This is the reason why non-Hausa Muslims refer to their Hausa Muslim 'brothers' as 'rats' (Saturday Champion, 9).

There is a tendency for negative hetero-stereotyping to be matched with a corresponding positive auto-stereotyping on identical elements. For example, from a religious point of view, the Hausas see themselves as God-fearing, thus superior, while at the same time seeing other Nigerian groups as pagans, fools and thus inferior (Ogunnika 1988). In the same vein, in the area of educational achievements, the Yoruba see themselves as very intelligent, modern, educated, progressive and enlightened, as opposed to others such as the Hausa who are backward, conservative and irrational. Sometimes, negative hetero-stereotyping is a reaction to traumatic historical experience. Ibo perception of the Hausa as 
being less civilized and envious need to be read in the light of the Hausa-Fulani massacre of Ibo dignitaries and people following the first military coup d'état in 1966 in Nigeria. Some other times, the negative stereotyping is linked to physical attributes and appearances. The 'strange' traditional costume of the Hausa-Fulani coupled with their visible facial tribal marks is not well understood and positively rated by the Ibos (Oha 2001). Yet some other times, negative hetero-stereotyping is linked to the collective behavior of the target group. For example, the tendency by the Fulani, predominantly Muslim, to perform ablution and to hit their heads on the ground while praying is looked down upon by the predominantly Christian Ibos (Oha 2001). Quite often however, negative heterostereotyping is linked to fear of the other. Ugwu has correctly identified the prevalence of fear-induced inter-ethnic misperceptions in urban areas, which may engender suspicion, discrimination and inter-communal clashes (Ugwu 2010).

Negative hetero-stereotyping often leads to derogatory name-calling usually highly connoted and which rather than encourage inter-communal proximity and accord in reality increase the chasm between groups. The Yorubas refer to Hausamen and women in such deriding terms as 'Gambari', 'Malam' or 'Sons/Daughters of Jaguda'. The first two terms point to low achievement levels by the Hausa in the realm of western education. The third refers to Jaguda, the first thief, believed to be a Hausaman, caught in Lagos. Referring to all Hausa people as descendants of a thief is hardly appreciated by those being so described (Ogunnika 1988). The Ibos are often referred to as 'Okoros', which is equally heavy with symbolic meaning as it conjures images of avarice and dishonesty (Ibid. 1988). The Hausa also refer to the Ibo as "Inyamiri", highly condescending as it conjures an image of low moral and ethical standards. The Idoma, a minority ethnic group in the Middle Belt, are referred to as "Okpoto" or "Akoto", which is associated with prostitution, easy women and low moral standards. One of the direct results of negative hetero-stereotyping is the establishment of distance rather than proximity in inter-group relations and coexistence as seen in segregated settlement patterns in major urban centers. In Northern Nigeria, predominantly Muslim, most cities are territorially dismembered, old traditional cities existing contiguous to 'sabongaris' or new towns. The traditional quarters are reserved to autochthonous populations and live by the tenets of islamwhile the sabongaris, open to immigrants, have a more cosmopolitan composition. Onwubu rightly qualifies 'sabongaris' or stranger quarters in Northern Nigerian cities as ethnic ghettos, established because "local Hausa inhabitants do not wish to mingle closely with the non-muslim infidels" (Onwubu 1975: 407).

It is difficult to manage inter-communal diversity and to contain possible conflicts between groups when such groups have negative and usually condescending opinions on others with which they share the same national territory. Negative hetero-stereotyping generates a deadly virus that leads to strained inter-communal rapport. They constitute a fertile ground on which intercommunal conflicts grow or can be easily sparked off. If authors like Horowitz 
(2001) view countries like Nigeria, Liberia and Côte d'Ivoire as theatres of deadly ethnic conflicts, this can be explained among others by strained inter-communal relations generated by disharmony in inter-ethnic perceptions. This is even more so when the ethnic groups are in competition for the same national resources. Nnoli (1995) is right when he says that the power of the State in Africa as the principal distributor of resources in reality impels individuals and ethnic groups to wish to seek the control of its apparatus. The same conclusion was reached by a conference organized by the CEPAC, Centre for Peace and Conflict Studies in Nigeria in February 2002 that the "intensification of identity-based struggles for control of power and resources" explain conflict-ridden inter-communal relations in Africa (Porter et al 2005: 2). The key solution adopted by Nigeria to diminish cut-throat inter-communal competition for national power and resources and accommodate the multitude of communal identities in a single post-colonial state structure is federalism.

\section{Nigerian Federalism}

Federalism has been chosen by Nigeria as the most suitable institutional tool for the accommodation of multiple ethno-regional identities. Rather than being the result of some form of inter-communal negotiation, the different communities willingly deciding and accepting to be together through some form of self-rule mixed with shared rule, Nigerian federalism as we know it today with a multiplicity of states was imposed to prevent the demise of the Nigerian State on the altar of Biafran irredentism. By reacting to Biafran secession and thus maintaining the territorial integrity of the Nigerian state, the creation of twelve states in 1967 also wished to attain a second objective which was to end the possible spiral of competition, mistrust and antagonism between duly constituted ethno-territorial groups. While on the one hand trying to eliminate centrifugal forces, Nigerian federalism on the other hand aimed to accommodate the same centrifugal forces. We agree with Jinadu (1985: 73.) that federalism in Nigeria, by 'providing the legal superstructure within which the various ethnic fractions of the political class seek access to state power with a view to controlling or influencing its exercise', has served to deflate inter-group tension and acrimony. The solution accommodates centrifugal pulls because it has put in place a regulatory mechanism for inter-group co-existence since each group, by being empowered to determine who gets what, where and how within its regional jurisdiction, is hardly in conflict with other groups who have the same powers in their own territories.

The key advantage of the federal solution has been to neutralize strains in inter-group relations by devolving power to territorial communities. It has enabled the diverse multinational postcolonial state to remain one by deescalating inter-communal conflicts and facilitating political stability. Nigerian federalism has allowed constituted ethno-regional groupings the possibility of governing themselves, in other words of distributing and redistributing political, economic and financial advantages among themselves. This way, the Nigerian federation can be regarded as a big salad bowl in which large chunks of 
communities are enveloped by a common degree of Nigerianness, even if loose or inchoate. In addition, the federal solution acknowledges the diverse nature of Nigeria and the manifest desire by communities within the country for some degree of self-rule which if unsatisfied would create large cracks in social relations. The short-lived experience under the first military regime of Ironsi for a unitary form of government clearly showed how such a choice was ill-suited to facilitating inter-communal accord. However, whether the federal solution has actually improved inter-communal relations is a different matter and highly debatable. As a solution to managing diversity and pluralism, Nigerian federalism seems paradoxically to have increased the social distance between groups for many reasons. The first is related to the phenomenon of scissiparity. Nigeria is compared to a biological cell that sub-divides and sub-divides again, creating more and more replicas of itself. From three states after independence in 1960, the number of states grew to 4 in 1963, to 12 in 1967, to 19 and a Federal Capital Territory in 1975, to 21 and a Federal Capital Territory in 1987, to 30 and a Federal Capital Territory in 1991, and finally to 36 and a Federal Capital Territory in 1996. The main result has been to weaken states to the advantage of the federal center. Many specialists of Nigerian federalism have underlined its overcentralized nature (Elaigwu 1988, Osaghae 1998). This means that the institutional decentralization of powers has not been accompanied by a real decentralization of material especially financial resources to states which depend almost exclusively on federally allocated revenue in order to perform their institutional and statutory obligations. Rather than deflate conflict at the national level by decentralizing competition for resources to sub-national or sub-federal arenas, state creation in Nigeria has paradoxically heightened group conflict over the control of the federal government, which in the final analysis remains the key locus of power, especially financial power.

A second reason is linked to the origins of demands for states or more states which we qualify as rejectionist in terms of orientation and political fiefdom building in terms of motivation. Nigerian federalism is rejectionist in orientation because is translates what Elaigwu (1988) calls an "avoidance mechanism" in inter-communal relations. Rather than accept otherness and be prepared to make compromises under a win-win relational form, in which the federating communities will mutually reinforce one another, Nigerian communities think that living with other communities will automatically lead to win-lose relational frameworks. Many do not wish to take the risk of being under such a framework for fear of not having the expected access to key political, administrative and economic advantages. This has fed the incessant demand for the creation of more states. Since such states provide the opportunity for regional power elites to have easier access to the "national cake", the motivation to demand more states is heightened even more.

A third manifestation of how federalism has increased the distance between Nigerian communities rather than improving inter-group accord is how the solution has engineered the development of the ideology of 'statism'. It is 
impossible in all Nigerian States for non-natives of a State to hold administrative, teaching, political or commercial positions of any consequence (Alapiki 2005). Such a situation has negative consequences on national integration and particularly on national identity building and citizenship. The question of national citizenship is beclouded by such categorizations as 'settlers', 'indigenes', 'nonindigenes' and 'migrants', categorizations which have led to 'an entrenched system of discriminatory practices in which non-indigenes are shunted out of or denied equal access to the resources, rights and privileges of a locality, community, town or state, to which 'sons and daughters of the soil' have first or exclusionary right' (Osaghae \& Suberu 2005: 8). The result is a hierarchical, unequal and ranked system of citizenship with full citizenship rights being place specific rather than national (Ibid. 2005: 8). Such a situation translates a clear failure at managing diversity because rather than lead to the establishment of a multicultural society where each of the component communities recognizes the existence of others in the same territory and acknowledge their right to the same privileges, what is established is a multi-communitarian society where there is inherent resentment between well-established communities. It is appropriate to try examining these two models of managing diversity using the Nigerian example: multiculturalism versus multi-communitarianism.

\section{Multiculturalism or Multi-communitarianism in Nigeria?}

Using the Nigerian example, we wish to develop in this section a tentative model of inter-communal relations. We believe that we have some key elements, based on our understanding of how the mosaic of ethno-cultural identity markers has been managed in the country, to define the architecture of such a model. Our opinion is that there are two possible models of managing inter-communal diversity. These are the multicultural and the multi-communitarian models. Both models differ in relation to such variables as the dominant forms of perceptions towards otherness or cultural difference, the level and degree of communication and contact between communities, the dominant attitudes towards out-group members (either pro-outgroup/acceptance or anti-outgroup/rejection), the dominant nature of hetero-stereotypes (whether negative of positive), and the political/administrative/territorial framework under which the various communities live, which either allow or limit communal self-rule. The multicultural model of managing diversity can be defined using Berry (1999: 13) according to who in order to maintain a "multicultural society in which all cultural groups find ways to live together", there needs to be many conditions including "overall low levels of intolerance and prejudice in the population" as well as "generally positive mutual attitudes among the various ethno-cultural groups that constitute the plural society". A multiculturally oriented model of managing inter-communal diversity would be one in which there is mutual acceptance and appreciation of otherness. Where there are high levels of prejudice and generally negative attitudes towards out-groups, the form of intercommunal relations is less likely to be mullticultural and more likely to be multicommunitarian. This is even more so if duly constituted ethno-cultural groups 
are allowed some form of self-rule which makes them intrinsically more in-group than out-group focused.

Our field work in Nigeria indicates a relatively high level of out-group prejudice given the unpreparedness for intermarriage between ethnic groups. Though at a purely inter-personal level, there are frequent relations between Nigerians from different ethnic extractions, the predominance of negative perceptions of members of different ethnic communities as a group, strains intercommunal communion and proximity. Such strains are rendered more difficult to overcome given an unintended consequence of, federalism, the institutional tool that has been adopted to manage inter-communal diversity, which is the tendency to view out-group members as strangers to be kept at arm's length. This is due to the policy of indigeneity which limits access to local government and state resources only to people indigenous to them. Given the relatively high level of ethno-communal self-rule allowed institutionally, the federal solution in Nigeria has in reality weakened rather than strengthened citizens' ability to communicate and feel solidarity across ethno-cultural differences. In a loose form of togetherness where there are continuous questions being raised about whether the federated units should continue to live together, there is no cementing national or Nigerian creed to ensure the proximity of the units. There is no cementing Nigerian creed because of the absence of a shared feeling of belonging to a Nigerian nation. 'We no wan put leg in the same trouser', a phrase commonly heard during informal discussions among some categories of Nigerians, aptly describes this tendency to refuse others as belonging to the same community. We agree with Abudu (1986: 31-32) when he says that "the concept of 'the Nigerian nation' is for most citizens a sentimental one to be exploited for personal advantages". Moreover, since the emergence of a strong nation-state has been hampered by centrifugal ethnic forces in Nigeria, many employees in the public sector owe more loyalty to their ethnic roots than to the Nigerian State which has little meaning beyond a geographical expression for many workers in public employment. We can present our thinking in the table below.

\begin{tabular}{|c|c|c|c|c|c|}
\cline { 3 - 5 } \multicolumn{2}{c|}{} & \multicolumn{2}{c|}{$\begin{array}{c}\text { Level of } \\
\text { outgroupprejudice }\end{array}$} & \multicolumn{2}{c|}{$\begin{array}{c}\text { Dominant form of } \\
\text { hetero stereotype }\end{array}$} \\
\cline { 3 - 6 } \multicolumn{2}{c|}{} & High & Low & Positive & Negative \\
\hline $\begin{array}{c}\text { Degree } \\
\text { of self- } \\
\text { rule of } \\
\text { ethno- } \\
\text { cultural } \\
\text { groups }\end{array}$ & Low & Nigeria & & & Nigeria \\
\cline { 2 - 6 } & & & & & \\
\hline
\end{tabular}


In Nigeria, there is a predominance of negative hetero-stereotypes coupled with a high level of out-group prejudice. In addition, there is a territorial system that allows duly constituted ethno-cultural groups, in the context of an incongruent federal structure, not only to govern themselves but also to prevent non-indigenes from access to political, administrative and economic advantages in their territory. The result is a multi-communitarian model of managing intercommunal diversity.

Nigeria has a multi-communitarian model of managing diversity with a high level of self-rule granted to communities, either within states or local government areas. Even if states and local governments all lack the necessary financial resources to be entirely self-ruling, the end result is for the various ethno-cultural groups to co-exist parallel to one another rather than be united in a common house. Each community tolerates the other as long as the other does not wish to have a bite on the community's share of the national cake. The specific model of multi-communitarian diversity management in Nigeria can be qualified as the zebra option or model. This is different from other methods of diversity management such as the 'melting pot' or 'menu chowder' models because in the zebra model, each community functions in a separate lane, wishes to do its thing its own way, has the institutional resources for self-management and may not negotiate with out-groups in assigning its priorities, mobilizing resources and reacting to the needs of its members. There are no strong ligaments or knots that tie the lanes together and incite them to move in a direction that will be mutually advantageous to all while reinforcing their togetherness. In reality, members of one group are indifferent to the rights and interests of the members of the other groups and are unwilling to make sacrifices for them. The zebra model differs from the other models specifically because whereas the others describe how multi-cultural communities have tried to maintain inter-group cohesion, this model expresses how various communities are made to cohabite as strange bedfellows in an each-group-in-its-separate-home form of relationship. The distinctions between groups remain marked and there are few instances of inter-communal union or fusion. Intermarriages between different groups are few and far between and out-group members are deconsidered outside the perimeter of their regions of origin.

\section{Conclusion}

Inter-communal diversity remains very salient in Nigeria. The 'we' versus 'them' schism is still very strong in the context of competition by all the communities for access to limited national resources. Rather than build bridges that will unite the multitude of communities living within its territory, Nigeria has chosen to satisfy centrifugal forces by granting some measure of self-government to duly constituted ethno-regional groupings. This has not incited communities to get to know themselves better. Even though inter-communal conflicts have been reduced, Nigeria has a failed model of multicultural management because the approach it has used is exclusionary rather than inclusionary. Federalism, negative hetero-stereotypes and out-group prejudice have led to a multi- 
communitarian society where communities are prepared to fight it out when they believe that their access to national resources is being blocked by other communities, equally anxious to have a better share of the national cake. The main solution that has been chosen to avoid such fights is to create additional states and local government units, each ethno-cultural community avoiding contact with others and happy to be the master of its own home and the resources that go with this. In our opinion, the zebra model of diversity management that has resulted has widened rather than reduced the distance between the component communities of post-colonial Nigeria. Consequently, 'United', the country preaches in many of its official statements including its national anthem and motto, but 'Divided' itmaintains through its various acts.

\section{Bibliography}

Abudu F., 1986, "Work attitudes of Africans with special reference to Nigeria", International Studies of Management and Organization, 16 (2), pp. 17-36.

Alapiki, H. E. 2005, “State creation in Nigeria's failed approaches to national integration and local autonomy", African Studies Review, 48, 3, December, pp. 4965.

Alan Tarr G., Robert W.F. \& Marko J.G. (eds), 2004, Federalism, Subnational Constitutions and Minority Rights, Westport CT, Praeger.

Berry J. W. 1999, "Intercultural relations in plural societies", Canadian Psychology, 40(1).

Elaigwu, J. I. 1988, "Nigerian federalism under civilian and military regimes", Publius, 18, 1, Winter, pp. 173-188.

Hewstone M. 1996, "Contact and categorizations: social psychological interventions to change intergroup relations", in C.N. Macrae et al (eds), Stereotypes and Stereotyping. New York: Guilford Press, pp. 323-368.

Horowitz D. 2011, The Deadly Ethnic Riot. Berkeley: University of California Press.

Jinadu A. L. 1985, "Federalism, the Consociational State and Ethnic Conflict in Nigeria", Publius, 15, 2, pp. 71-100.

Kymlicka W. 2001, Politics in the Vernacular: Nationalism, Multiculturalism and Citizenship, Oxford: OUP.

Kymlicka W. \& Wayne N. 2000 (eds), Citizenship in Diverse Societies, Oxford: OUP.

Lijphart A. 1984, Democracies: Patterns of Majoritarian and Consensus Government in Twenty-One Countries, New Haven: Yale University Press.

Monden C.W.S. \& Jeroen S. 2005, "Ethnic intermarriage in times of social change: The case of Latvia", Demography, 42, 2, pp. 323-340.

Morris-Hale W. 1997, Conflict and Harmony in Multi-Ethnic Societies: An International Perspective, New York: Peter Lang. 
Nnoli O. 1995, Ethnicity and Development in Africa, Aldershot: Ashgate.

Ogunnika O. 1988, "Inter-ethnic tension management and control in a Nigerian city", International Journal of Politics, Culture and Society, 1, 4, Summer, pp. 519-537.

Oha O. 2001, "MmanwuAwusa: Masquerading the Hausa Muslim in Igbo Tiger Performance". Taken from www.ethnonet-africa.org/pubs/crossroadsoha.htm Onwubu C. 1975, "Political integration and national development: The Igbo diaspora in Nigeria", The Journal of Modern African Studies, Vol. 13, 3, pp. 399-413.

Osaghae, Eghosa E. 1998, "Managing multiple minority problems in a divided society: The Nigerian experience", The Journal of Modern African Studies, Vol. 36, 1, pp. 1-24.

Osaghae Eghosa E. \& Rotimi T. S 2005, "A history of identities, violence and stability in Nigeria", CRISE Working Paper, January. Taken from www.crise.ox.ac.uk/pubs/workingpaper6.pdf

Ostien P., "Jonah Jang and the Jasawa: Ethno-religious conflict in Jos, Nigeria". Muslim-Christian Relations in Africa. Taken from www.sharia-in-africa.net

Porter E., Robinson G., Smith M., Albrecht S. \& Eghosa O. 2005, Researching Conflict in Africa. Insights and Experiences, Tokyo: United Nations Press.

Resnick P. 1994, “Towards a multination federalism”, in Leslie Seidle (ed), Seeking a New Canadian Partnership: Asymmetrical and Confederal Options, pp. 71-90, Montreal: Institute of Public Policy.

Richard J. 1991, Democracy and Prebendal Politics in Nigeria: The rise and fall of the Second Republic, Ibadan: Spectrum Books.

Rothchild D. 1997, Managing Ethnic Conflict in Africa: Pressures and Incentives for Cooperation, Washington, DC: Brookings Institution.

Saturday Champion, 20 March 2004, p. 9.

Stephan W. G. \& Cookie White S. 1996, Intergroup Relations, Boulder, CO: Westview Press.

Ugwu L. I., 2010, "Governing micro-ethnicity in contemporary urban and semiurban spaces in Africa: A sociological analysis", European Journal of Social Sciences, Vol. 18, 2.

Yueh-Ting L., Lee J. Jussimand Clark R. McCauley (eds) 1995, Stereotype Accuracy: Towards Appreciating Group Differences, Washington: American Psychological Association. 